\title{
Correlation between Electrical Resistivity, Particle Dissolution, Precipitation of Dispersoids, and Recrystallization Behavior of AA7020 Aluminum Alloy
}

\begin{abstract}
A.R. EIVANI, H. AHMED, J. ZHOU, and J. DUSZCZYK
This research concerns the effect of homogenization treatment on the electrical resistivity of AA7020 aluminum alloy variants with different $\mathrm{Zr}$ and $\mathrm{Cr}$ contents. Small changes in the $\mathrm{Zr}$ and $\mathrm{Cr}$ contents of the as-cast alloy increase the electrical resistivity significantly. After employing various homogenization treatments, the electrical resistivity decreases, which is due to the depletion of $\mathrm{Zr}, \mathrm{Cr}$, and $\mathrm{Mn}$ in the matrix, by forming small dispersoids. The optimum treatment proposed in order to obtain the smallest recrystallized grains is to hold the material at $550{ }^{\circ} \mathrm{C}$ for 24 hours, which results in the lowest electrical resistivity. The viability of the proposed treatment was tested through hot compression tests and static annealing. Indeed, the samples homogenized at $550{ }^{\circ} \mathrm{C}$ for 24 hours showed the smallest recrystallized grains compared to those homogenized at other temperatures.
\end{abstract}

DOI: $10.1007 / \mathrm{s} 11661-009-9917-\mathrm{y}$

(C) The Author(s) 2009. This article is published with open access at Springerlink.com

\section{INTRODUCTION}

ONE of the primary objectives of the homogenization treatment applied to direct-chill cast aluminum alloys before hot deformation is to create small dispersoids that later act as recrystallization inhibitors during deformation and annealing treatments. ${ }^{[1]}$ In industrial practice, the billet is homogenized at a temperature in a range from $450{ }^{\circ} \mathrm{C}$ to $480{ }^{\circ} \mathrm{C}$, under strict control of the heating rate and time, in order to produce a distribution of fine dispersoids at grain boundaries. ${ }^{[1]}$ In 3XXXseries aluminum alloys, for example, $\mathrm{Mn}$ in solid solution and $\mathrm{Mn}$-containing dispersoids, formed during homogenization, play an important role in controlling the recrystallization behavior of the alloys. ${ }^{[2-4]}$ In 6XXX-series aluminum alloys, the formation of different kinds of dispersoids, i.e., Zr-, Mn-, and Cr-containing dispersoids, which play the role of recrystallization inhibition, has been investigated. ${ }^{[5-9]}$ In the case of 7XXX-series aluminum alloys, the formation of $\mathrm{Zr}$ - and Sc-containing dispersoids has been investigated. ${ }^{[10-16]}$ For example, Robson et al. ${ }^{[10,11]}$ investigated the effect of $\mathrm{Zr}$ addition on the dispersoid formation and recrystallization fraction after hot deformation. It was concluded that, when using an optimum two-step homogenization treatment, a smaller fraction of recrystallization could be obtained. Robson ${ }^{[12]}$ also considered the effect of Sc on the formation of dispersoids, because Sc was expected to eliminate the dispersoid-free zones,

A.R. EIVANI and H. AHMED, Postdoctoral Researchers, are with the Materials Innovation Institute, 2628 CD Delft, The Netherlands. J. ZHOU and J. DUSZCZYK, Associate Professors, are with the Department of Materials Science and Engineering, Delft University of Technology, 2628 CD Delft, The Netherlands. Contact e-mail: eivani@m2i.nl

Manuscript submitted January 5, 2009.

Article published online August 12, 2009 observed in scandium-free 7050 , thus greatly increasing the recrystallization resistance. Senkova et al. ${ }^{[13]}$ and Senkov et al. ${ }^{[14]}$ investigated the effect of minor additions of $\mathrm{Sc}$ and $\mathrm{Zr}$ on the tensile properties of two developmental $\mathrm{Al}-\mathrm{Zn}-\mathrm{Mg}-\mathrm{Cu}$ alloys in the temperature range of $-196{ }^{\circ} \mathrm{C}$ to $300{ }^{\circ} \mathrm{C}$. They concluded that, due to the presence of $\mathrm{Sc}$ and $\mathrm{Zr}$ in a fine-dispersoid form, both low-temperature and elevated-temperature strengths of these alloys were much higher than those of similar 7XXX-series alloys that did not contain these elements. Morere et al. ${ }^{[15]}$ investigated the influence of $\mathrm{Al}_{3} \mathrm{Zr}$ dispersoids on the static recrystallization of hotdeformed AA7010 alloys. It was found that the fraction recrystallized decreased with increasing $\mathrm{Zr}$ content, rising deformation temperature, and decreasing dispersoid size. However, finding a comprehensive investigation of the formation of $\mathrm{Cr}$ - and $\mathrm{Mn}$-containing dispersoids in $7 \mathrm{XXX}$-series aluminum alloys during homogenization and its effect on the recrystallization resistance is difficult.

It is well known that the presence of alloying elements or impurities in solid solution increases the electrical resistivity of aluminum alloys. ${ }^{[17,18]}$ Moreover, the presence of small particles in the structure, such as precipitates or dispersoids, causes significant scattering of conduction electrons and, hence, increases the electrical resistivity of an alloy. ${ }^{[17,18]}$ The size and distribution of small particles affect the electrical resistivity of the alloy. ${ }^{[5,19-21]}$ The contribution of precipitates and dispersoid particles could be neglected if the precipitate spacing is greater than the mean free path of the electron, i.e., particle spacings larger than $100 \mathrm{~nm}$ in aluminum alloys. ${ }^{[18]}$ In the intermediate range of precipitate and dispersoid particle spacings commonly observed in commercial aluminum alloys, the contribution of precipitates to electrical resistivity is less clear. Scanning electron microscopy (SEM) and transmission 
electron microscopy (TEM) confirm the formation about small particles during homogenization, which affects the electrical resistivity. ${ }^{[10-16]}$ Therefore, the electrical resistivity analysis can be used as an indirect means of evaluating the volume fraction of dispersoids and the dissolution of constitutive particles during the homogenization of aluminum alloys.

There is much research on the effect of stable and metastable precipitates during precipitation hardening on the electrical resistivity of aluminum alloys. For example, Thakur et al. ${ }^{[20]}$ studied the effect of natural aging on the resistivity evolution during the artificial aging of an Al-Zn-Mg-Zr alloy. Ferragut ${ }^{[22]}$ performed a pre-precipitation study on the AA7012 alloy by measuring its electrical resistivity. Asano ${ }^{[23]}$ investigated the nucleation of precipitates in $\mathrm{Al}-\mathrm{Zn}-\mathrm{Mg}$ alloys using electrical resistivity measurements. All of the researchers have concluded that the presence of elements in the solid solution and small particles possessing coherent interfaces increases the electrical resistivity. ${ }^{[20,22,23]}$ Similar observations have also been reported in the case of 6XXX-series aluminum alloys. ${ }^{[21,24-26]}$ However, the information available on the effects of homogenization treatment on electrical resistivity is scarce in the literature, especially in the case of 7XXX-series aluminum alloys. For example, Lodgaard and Ryum ${ }^{[5]}$ studied the precipitation of $\mathrm{Mn}$ - and $\mathrm{Cr}$-containing dispersoids in Al-Mg-Si alloys using electrical resistivity and optical microscopy with a special emphasis on the nucleation mechanism. They predicted the formation of an intermediate $u$ phase, rich in $\mathrm{Mn}$ and $\mathrm{Cr}$, which later acted as heterogeneous nucleation sites for Mn-containing dispersoids. These results primarily concerned the decrease in the electrical resistivity of the alloy during homogenization, which is likely due to the depletion of the elements in the matrix and the formation of the dispersoids. However, a correlation between the effect of the homogenization treatment (e.g., the formation of dispersoids and the dissolution of constituent particles) and the evolution of the electrical resistivity was not established. Li and Arnberg ${ }^{[4,27]}$ investigated the precipitation behavior of dispersoids in the direct-chill (DC)cast AA3103 alloy during heating and homogenization at $600{ }^{\circ} \mathrm{C}$ by means of TEM, electrical resistivity measurement, and image analysis. The presence of $\mathrm{Al}(\mathrm{Mn}, \mathrm{Fe}) \mathrm{Si}$ dispersoids as the first phase to precipitate in the alloy and then the precipitation of $\mathrm{Al}_{6}(\mathrm{Mn}, \mathrm{Fe})$ dispersoids during heating to a high homogenization temperature was predicted. They found a good agreement between the volume fractions of dispersoids calculated by TEM and electrical resistivity measurements. Vooijs et al. ${ }^{[28]}$ monitored multiple precipitation reactions in an AA3104 and a Mg- and Cu-rich AA3104 alloy during isothermal annealing using TEM, thermoelectric power, and electrical resistivity; they found good agreement among the results of the different methods. These investigations indicate the capability of electrical resistivity measurements to predict the volume fraction of dispersoids formed during homogenization.

The objective of this research was to evaluate the effects of chemical composition and homogenization treatment on the evolution of the electrical resistivity of the AA7020 aluminum alloy, which could be used as an indirect means of optimizing the homogenization treatment of the AA7020 aluminum alloy. To achieve this objective, the correlation between the electrical resistivity, dispersoid formation, and particle dissolution was established. The application of the electrical resistivity to optimize the homogenization process needs a deep knowledge of the events occurring during the process. An optimum treatment for obtaining the smallest recrystallized grain size was proposed, validated by the investigation of the recrystallized grain structure after uniaxial hot compression testing and static annealing. The proposed homogenization conditions are in contradiction to those proposed in the literature for AA7020-series aluminum alloys but, indeed, result in effective recrystallization inhibition.

\section{EXPERIMENTAL PROCEDURES}

Specimens $2 \mathrm{~cm}^{3}$ in size were cut from the center of a DC-cast AA7020 ingot. The chemical compositions of the specimens used in this study are shown in Table I. Isothermal homogenization treatments were performed in a salt bath at temperatures of $390{ }^{\circ} \mathrm{C}$ to $550{ }^{\circ} \mathrm{C}$, for 2 to 48 hours at each temperature. Following the heat treatments, the samples were water quenched.

For electrical resistivity measurements, the samples were mechanically polished up to $1 \mu \mathrm{m}$. The electrical resistivity was measured by the eddy current technique using a Sigmatest D 2.068 (CORVIB Precision Measurement Instruments, Weston, Canada) operating at room temperature and at a rate of $60 \mathrm{~Hz}$. The surface area of the probe was $1 \mathrm{~cm}^{2}$. More than 10 electrical resistivity measurements were performed for each sample and an average value was reported.

Optical microscopy was performed using an OLYMPUS BX60M optical microscope (Spectra Services Inc., Ontario, NY) on the samples etched, using Barker's etchant. The images were analyzed using a soft-imaging software (SIS) analyzer to determine the volume fraction of the particles present in the microstructure. Moreover, a BRUKER-AXS D5005 diffractometer with a $\mathrm{Cu} K_{\alpha 1}$ wavelength was used to identify the phases present in the as-cast and as-homogenized structures.

Table I. Chemical Compositions of Samples Used in This Investigation

\begin{tabular}{lcccccccccc}
\hline Element (Wt Pct) & $\mathrm{Si}$ & $\mathrm{Fe}$ & $\mathrm{Cu}$ & $\mathrm{Mn}$ & $\mathrm{Mg}$ & $\mathrm{Zn}$ & $\mathrm{Ti}$ & $\mathrm{Cr}$ & $\mathrm{Zr}$ & $\mathrm{Al}$ \\
\hline N1 & 0.31 & 0.28 & 0.20 & 0.34 & 1.24 & 4.36 & 0.001 & 0.10 & 0.08 & bal \\
N2 & 0.30 & 0.30 & 0.19 & 0.35 & 1.20 & 4.37 & 0.002 & 0.10 & 0.13 & bal \\
N3 & 0.29 & 0.31 & 0.20 & 0.36 & 1.22 & 4.37 & 0.001 & 0.10 & 0.20 & bal \\
N4 & 0.30 & 0.30 & 0.21 & 0.36 & 1.22 & 4.35 & 0.001 & 0.40 & 0.13 & bal \\
\hline
\end{tabular}


The samples were examined using a JEOL* 6500 field

*JEOL is a trademark of Japan Electron Optics Ltd., Tokyo.

emission gun (FEG)-SEM. The optimum operating voltage and current were found to be $10 \mathrm{kV}$ and $1 \mathrm{nA}$, respectively. To estimate the dispersoid interspacing, the SIS image analyzer was employed. The distances between a dispersoid particle and its nearest neighbors were calculated on two samples at each condition, with three images in each sample and more than 20 dispersoids in each image; the average value was reported.

Energy-dispersive X-ray (EDX) analysis was performed with an analyzer attached to the FEG-SEM, to determine the chemical compositions of the particles in the structure. In order to keep the analysis volume in the EDX measurements as small as possible, the analysis was performed on TEM samples with an average thickness of $100 \mathrm{~nm}$ or less. Disks with a diameter of $3 \mathrm{~mm}$ were punched from the samples and ground down to less than $60 \mu \mathrm{m}$, followed by electropolishing in a double-jet polishing unit at $20 \mathrm{~V}$ in a solution of 30 pct nitric acid and 70 pct methanol cooled to $-25^{\circ} \mathrm{C}$. The EDX analysis was performed at different areas in each sample and an average of 10 measurements was reported.

For electron probe microanalysis (EPMA), the measurements were performed with a JEOL JXA 8900R microprobe using an electron beam with energy of $15 \mathrm{keV}$ and a beam current of $50 \mathrm{nA}$, employing wavelength-dispersive spectrometry. The composition at each analysis location of the sample was determined using the X-ray intensities of the constituent elements after background correction relative to the corresponding intensities of reference materials. The points of analysis were located on lines with increments of $2 \mu \mathrm{m}$ and involved the elements $\mathrm{Cr}, \mathrm{Mn}, \mathrm{Cu}$, and $\mathrm{Zr}$. The $\mathrm{Al}$ was measured by difference.

In order to verify the viability of the proposed homogenization treatment and the application of the electrical resistivity technique in predicting the formation of dispersoids during homogenization treatment, the recrystallization response of the specimens after hot deformation and static annealing was investigated. Hot compression specimens were prepared as cylinders with a diameter of $10 \mathrm{~mm}$ and a length of $12 \mathrm{~mm}$ from the material $\mathrm{N} 1$; these were homogenized at $390{ }^{\circ} \mathrm{C}, 470{ }^{\circ} \mathrm{C}$, $510{ }^{\circ} \mathrm{C}$, and $550{ }^{\circ} \mathrm{C}$ for 24 hours. The uniaxial hot compression tests were conducted at $450{ }^{\circ} \mathrm{C}$ at a strain rate of $10 \mathrm{~s}^{-1}$, using a DSI Gleeble 3800 thermomechanical simulator (Dynamic Systems Inc., Poestenkill, NY). Compression deformation proceeded to a strain of 0.6. The tests were performed at least twice for each condition to ensure the repeatability of the data. The specimens were heated to $450{ }^{\circ} \mathrm{C}$ at a rate of $10{ }^{\circ} \mathrm{C} / \mathrm{s}$ and kept at that temperature for 110 seconds, in order to attain a homogenous temperature in the test material and anvils, based on the previous studies using the same facility. ${ }^{[29]}$ The specimens were subsequently water quenched to freeze the as-deformed structure, to ensure that no further microstructural changes would occur after deformation.
To investigate the effect of post-deformation annealing, the specimens were annealed in a salt bath at $575^{\circ} \mathrm{C}$ for 10 minutes. These were cut through thickness and the grain structure at the central regions of the compression specimens was subsequently studied by using a polarized light optical microscope. The average grain size was determined using the general line intercept procedure according to ASTM E $112-96 .^{[30]}$

\section{RESULTS}

\section{A. Electrical Resistivity Evolution}

\section{Effect of chemical composition on electrical resistivity}

Figure 1 shows the effect of the chemical composition of the samples on the electrical resistivity, which illustrates the increases in the electrical resistivity from $\mathrm{N} 1$ to N4. It is clear that the electrical resistivity of the samples increases from N1 to N3, which have differences in $\mathrm{Zr}$ content in their chemical compositions (Table I). The N4, with the largest percentage of $\mathrm{Cr}$, has the highest electrical resistivity. It is clear that, with an increase in the $\mathrm{Zr}$ content by 0.05 pct from N1 to N2 or from $\mathrm{N} 2$ to $\mathrm{N} 3$, the electrical resistivity of the alloy increases by 2 pct. Moreover, the electrical resistivity increases by 17.6 pet with increasing $\mathrm{Cr}$ content from 0.1 to 0.4 pet.

\section{Effect of homogenization treatment on electrical resistivity}

Figures 2(a) through (d) show the effect of the homogenization time on the electrical resistivity of the samples homogenized at $390{ }^{\circ} \mathrm{C}, 470{ }^{\circ} \mathrm{C}, 510{ }^{\circ} \mathrm{C}$, and $550{ }^{\circ} \mathrm{C}$. It is clear that the electrical resistivity of the material decreased with increasing holding time during

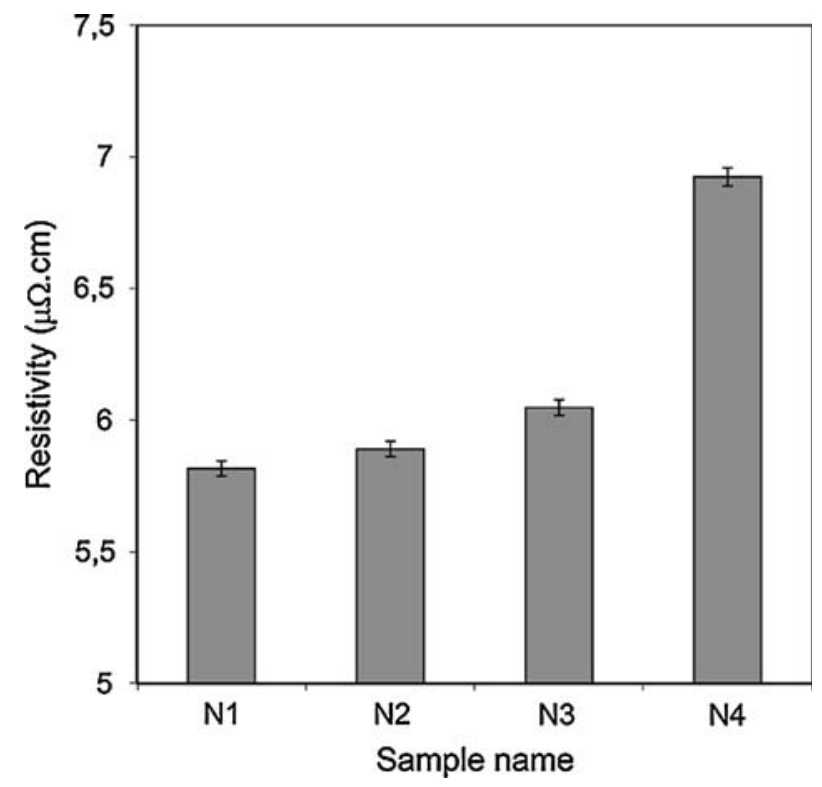

Fig. 1-Effect of chemical composition on electrical resistivity of the as-cast samples. 


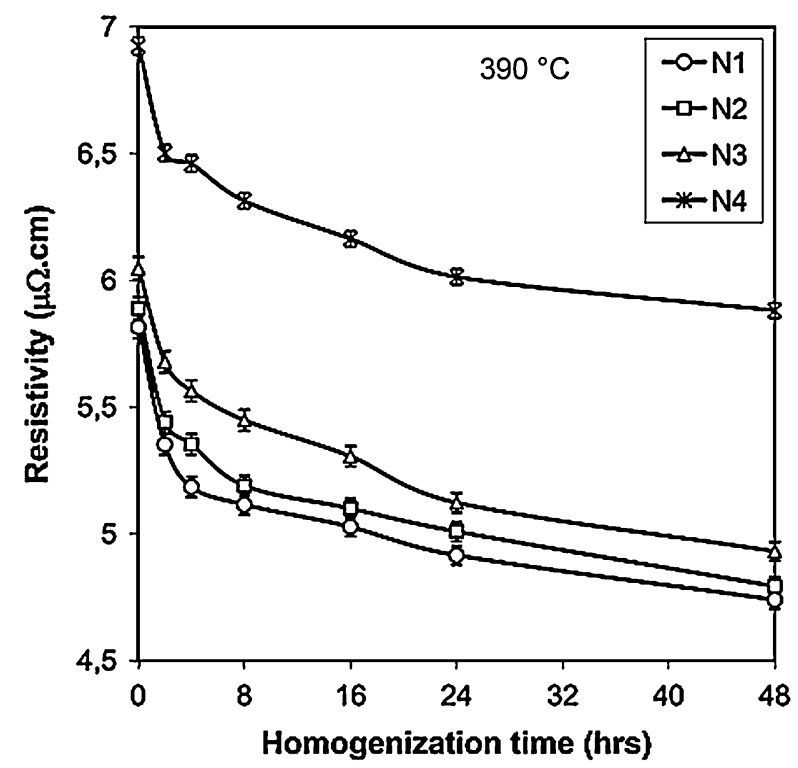

(a)

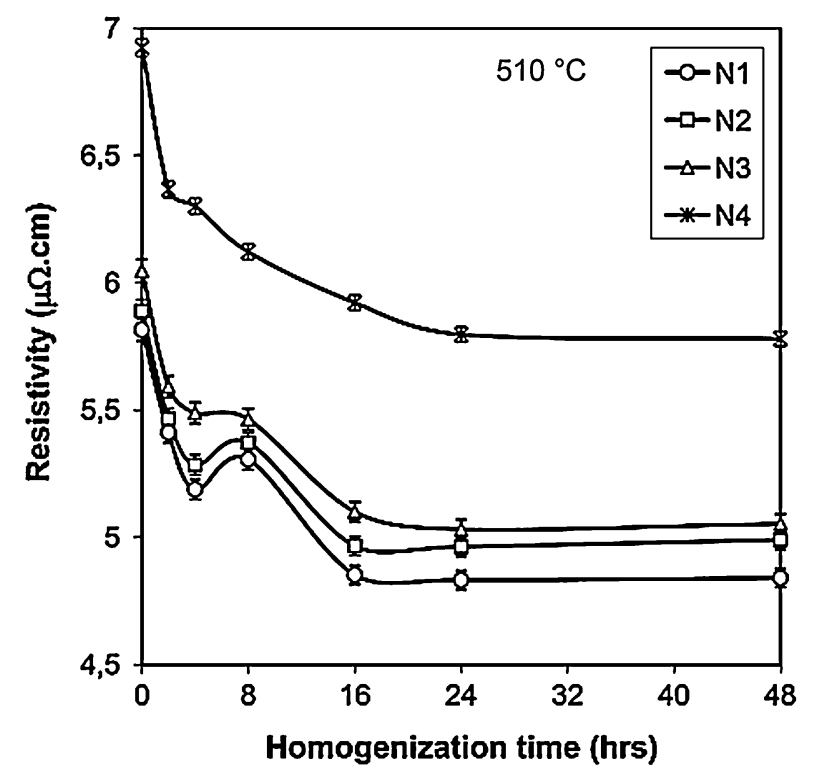

(c)

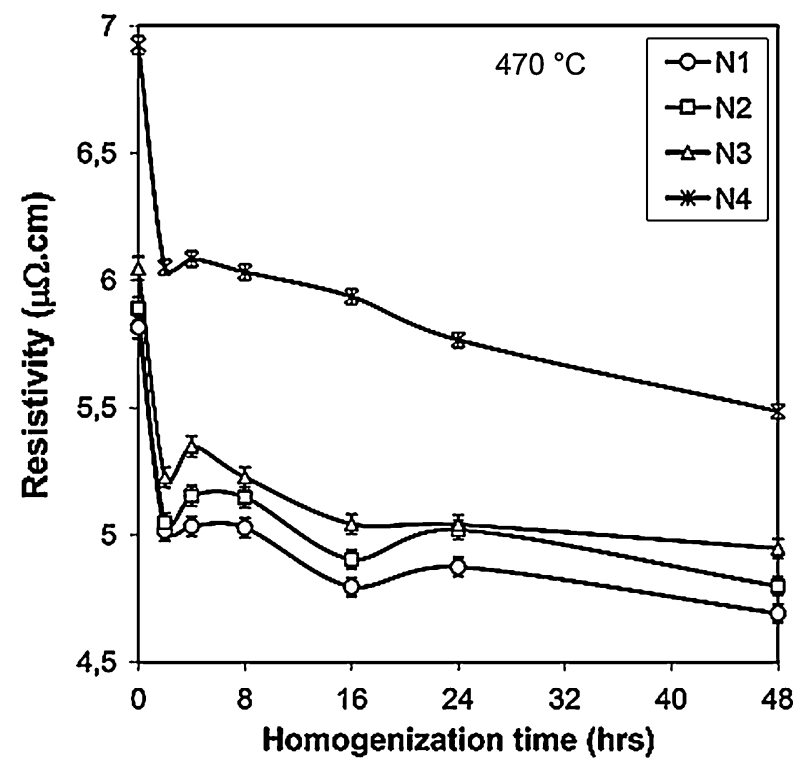

(b)

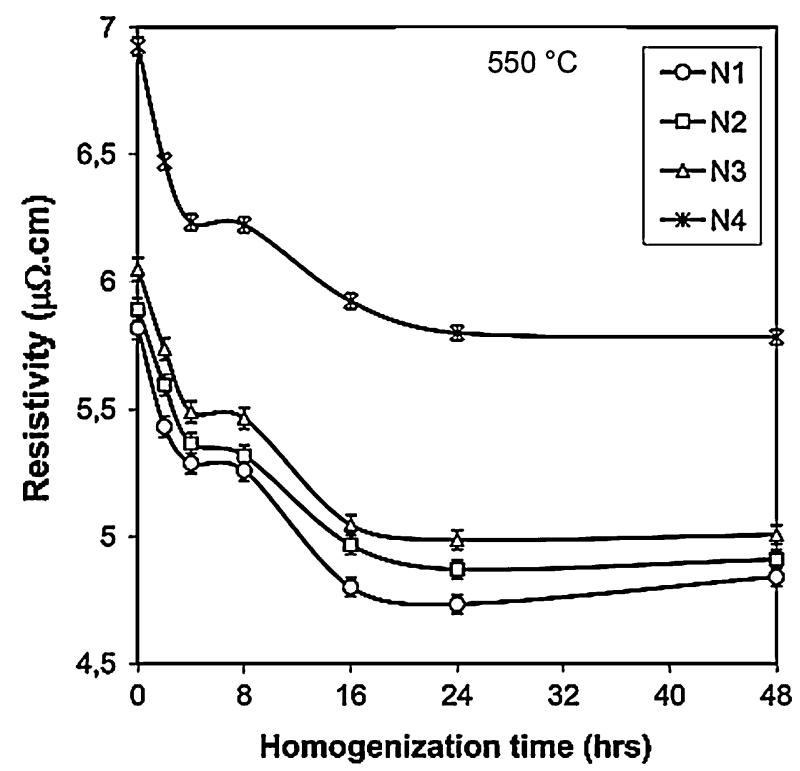

(d)

Fig. 2-Effect of homogenization treatment on electrical resistivity.

homogenization. It can also be seen that the most significant decrease in the electrical resistivity occurs at the first 2 hours of homogenization. In addition, some differences are observed when different homogenization temperatures and the compositions of the materials are compared. For example, at $390{ }^{\circ} \mathrm{C}$, the electrical resistivity shows a steep decrease (between 0 to 4 hours) and then a continuous decrease up to 48 hours (Figure 2), while at $470{ }^{\circ} \mathrm{C}, 510{ }^{\circ} \mathrm{C}$, and $550{ }^{\circ} \mathrm{C}$, the electrical resistivity shows a steep decrease (between 0 to 4 hours) and then an increase leading to a peak or a plateau (between 4 to 8 hours), followed by a decrease (between 8 to 16 hours), until it reaches a nearly constant value after a hold time of 16 to 24 hours. Figures 2 (c) and (d) show that, during homogenization at high temperatures $\left(510{ }^{\circ} \mathrm{C}\right.$ to $\left.550{ }^{\circ} \mathrm{C}\right)$, the electrical resistivity becomes constant after 16 to 24 hours, while during homogenization at low temperatures $\left(390^{\circ} \mathrm{C}\right)$, the reduction in the electrical resistivity continues until the end of the process (48 hours).

\section{B. Formation of Dispersoids}

The effect of homogenization treatment on the formation of small dispersoids is shown in Figure 3, as an example. It is clear that, during homogenization, small dispersoids having a radius less than $100 \mathrm{~nm}$ form. The average distance between the dispersoids changes 
with the homogenization temperature and time, as shown in Figure 4. It is clear that all the dispersoid interspacing is greater than $100 \mathrm{~nm}$, regardless of the homogenization treatment, which is in agreement with the results of other research on AA7050, ${ }^{[10,11]}$ AA $7475,{ }^{[31]}$ and other alloys. ${ }^{[14]}$

The results of EDX analysis on dispersoids formed at different homogenization conditions are shown in Table II. It is possible to identify at least four different types of dispersoids, $\mathrm{Zr}$ - (type 1), $\mathrm{Cr}$ - (type 2), and Mn-containing (type 3) dispersoids, and those that have a combination of various elements (type 4). It should be noted that the Mn-containing dispersoids
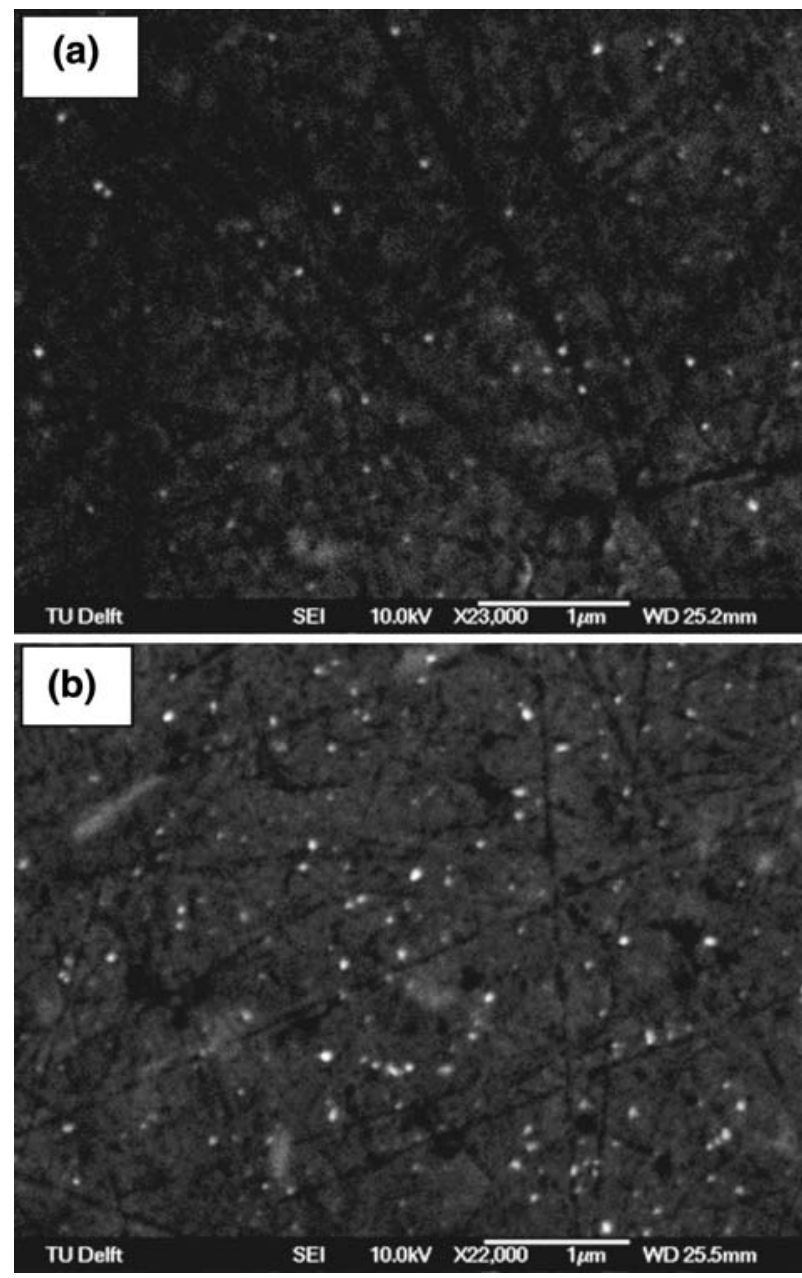

Fig. 3-Typical FEG-SEM images showing interspacings of small particles in sample $\mathrm{N} 1$ formed during homogenization at $(a) 510{ }^{\circ} \mathrm{C}$ for $2 \mathrm{~h}$ and (b) $510{ }^{\circ} \mathrm{C}$ for $8 \mathrm{~h}$. (type 3) are only observable after homogenization at $510{ }^{\circ} \mathrm{C}$ and higher, and especially for a holding time of at least 4 hours. The number density of Mn-containing dispersoids is higher in the regions close to the $\mathrm{Al}_{17}\left(\mathrm{Fe}_{3.2} \mathrm{Mn}_{0.8}\right) \mathrm{Si}_{2}$ particles. It should be also noted that the number density of type 4 dispersoids in the material is small. ${ }^{[32]}$

\section{Dissolution of Constitutive Particles}

Figure 5 shows the optical microstructure of the material $\mathrm{N} 1$ in the as-cast condition and after 2 hours of homogenization at different temperatures. The results of the EDX analysis together with the X-ray diffraction (XRD) analysis shown in Table III indicate that a large percentage $(70 \mathrm{pct})$ of the particles in the initial structure are the $\mathrm{Al}_{17}\left(\mathrm{Fe}_{3.2} \mathrm{Mn}_{0.8}\right) \mathrm{Si}_{2}$ particles, ${ }^{[33]}$ and the other particles are $\mathrm{Cu}-, \mathrm{Mg}-$, and $\mathrm{Zn}$-containing ones. ${ }^{[3,34]} \mathrm{It}$ can be seen that homogenization at $390^{\circ} \mathrm{C}$ led to an increase in the volume fraction of particles. The particles formed during homogenization at this temperature were found to be $\mathrm{Mg}_{2} \mathrm{Si}$ and $\mathrm{MgZn}_{2}$ precipitates. ${ }^{[33]} \mathrm{At}$ $510{ }^{\circ} \mathrm{C}$ and $550{ }^{\circ} \mathrm{C}$, the volume fraction of particles decreased, which was due to the dissolution of $\mathrm{Al}_{17}\left(\mathrm{Fe}_{3.2} \mathrm{Mn}_{0.8}\right) \mathrm{Si}_{2}$ particles. ${ }^{[33]}$

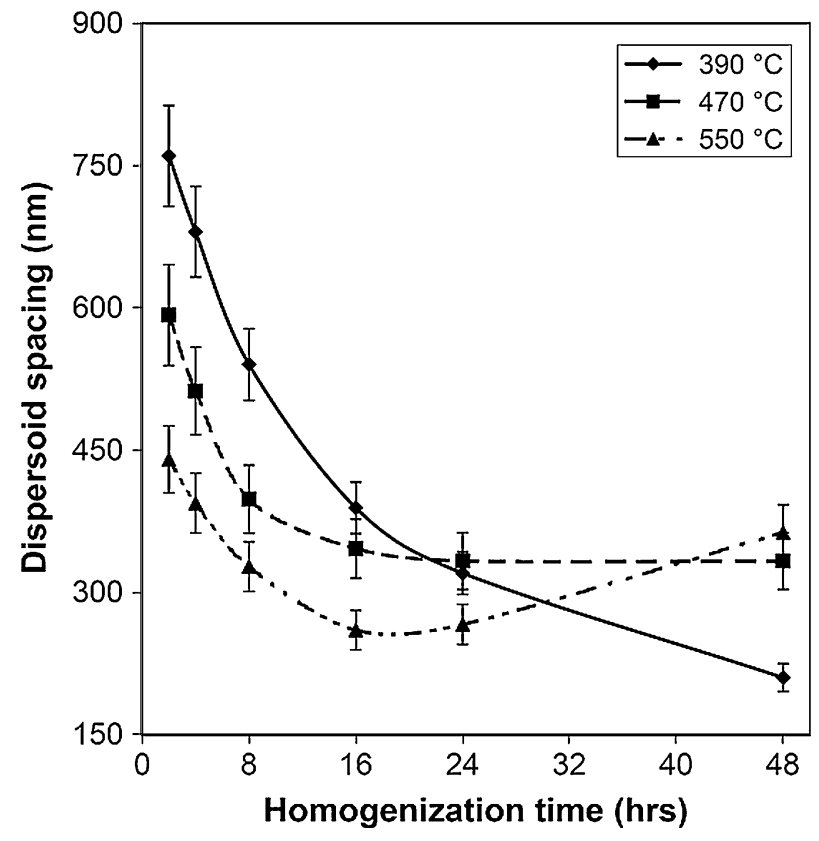

Fig. 4-Average dispersoid interspacing in sample S1as a function of homogenization time at different temperatures (SEM analysis).

Table II. Characteristics of Different Types of Dispersoids in AA7020 after 4 Hours of Homogenization at Different Temperatures

\begin{tabular}{|c|c|c|c|c|c|c|c|c|c|}
\hline Dispersoid Types & Major Elements & Formation Conditions & $\mathrm{Mg}$ & $\mathrm{Fe}$ & $\mathrm{Zn}$ & $\mathrm{Zr}$ & $\mathrm{Cr}$ & $\mathrm{Mn}$ & $\mathrm{Al}$ \\
\hline Type 1 & $\mathrm{Zr}$ & all & 0.08 & 0.67 & 0.10 & 11.90 & 0.30 & 0.09 & 86.86 \\
\hline Type 2 & $\mathrm{Cr}, \mathrm{Fe}$ & all & 0.23 & 11.00 & 0.82 & 0.60 & 34.10 & 0.03 & 53.22 \\
\hline Type 3 & $\mathrm{Mn}, \mathrm{Fe}$ & $T \geq 510^{\circ} \mathrm{C}$, time $\geq 4 \mathrm{~h}$ & 0.09 & 7.30 & 0.26 & 0.20 & 0.02 & 12.80 & 79.33 \\
\hline Type 4 & $\mathrm{Mg}, \mathrm{Zn}, \mathrm{Fe}$ & all & 4.59 & 3.20 & 10.24 & 0.07 & 0.12 & 0.07 & 81.71 \\
\hline
\end{tabular}




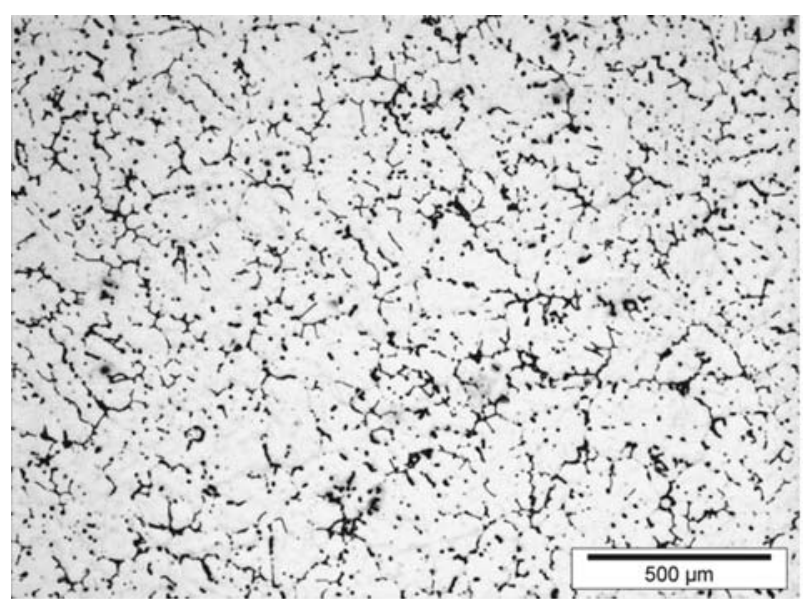

(a)

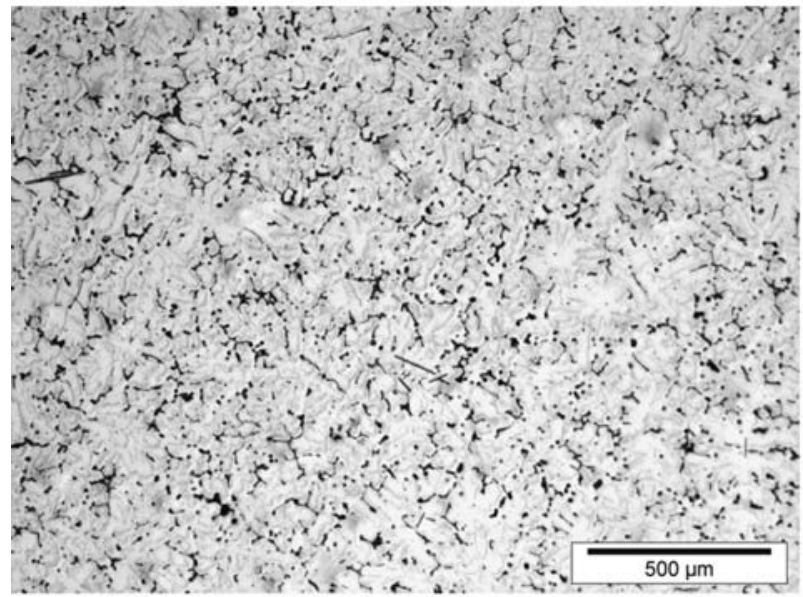

(c)

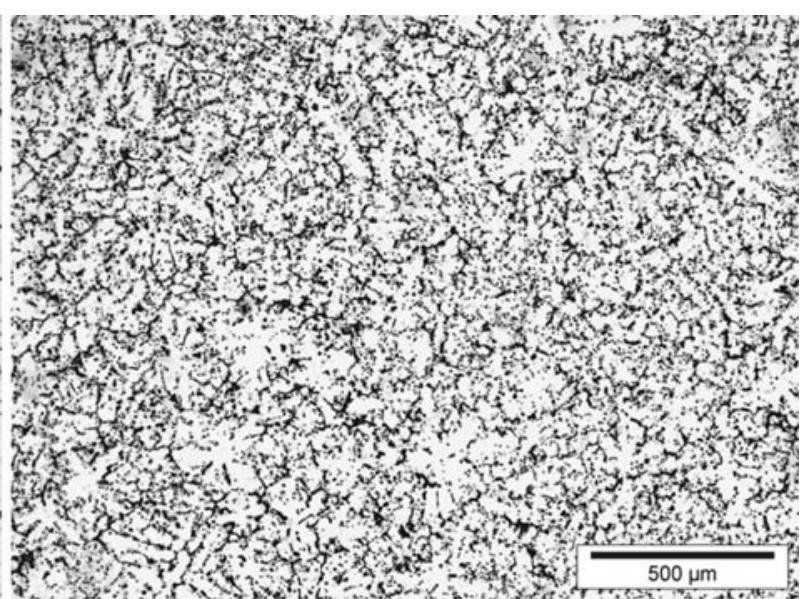

(b)

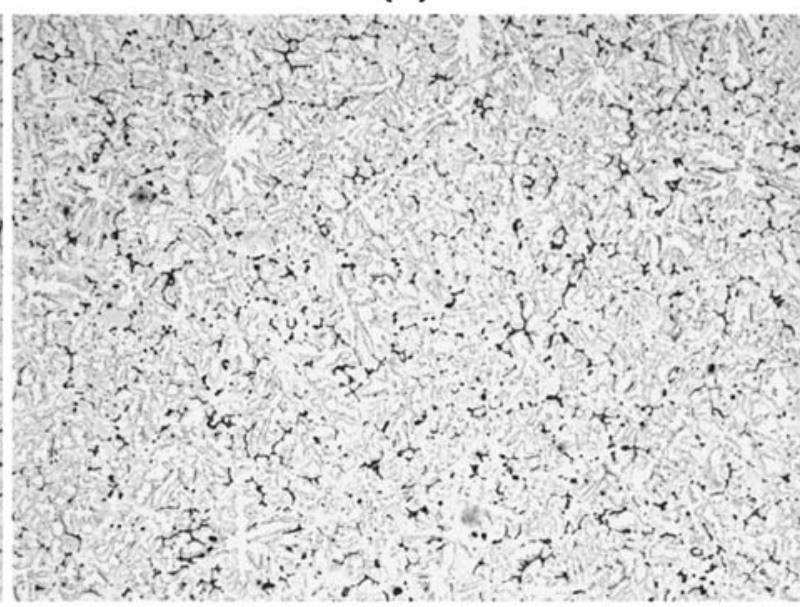

(d)

Fig. 5-Effect of homogenization treatment for $2 \mathrm{~h}$ at different temperatures on the evolution of constitutive particles in sample N1: $(a)$ initial structure, (b) $390{ }^{\circ} \mathrm{C},(c) 510{ }^{\circ} \mathrm{C}$, and $(d) 550{ }^{\circ} \mathrm{C}$.

Table III. Measured Mean Compositions (Weight Percent) of Grain-Boundary-Constitutive Particles in As-Cast Material Together with Calculated Chemical Compositions of Phases Identified from XRD Analysis

\begin{tabular}{|c|c|c|c|c|c|c|}
\hline Element & $\mathrm{Al}$ & $\mathrm{Fe}$ & Mn & $\mathrm{Si}$ & $\mathrm{Zn}$ & $\mathrm{Cu}$ \\
\hline Grain boundary (EDX) & $72 \pm 3$ & $16 \pm 2$ & $3 \pm 1$ & $4 \pm 1$ & $3 \pm 1$ & $2.0 \pm 0.4$ \\
\hline $\mathrm{Al}_{17}\left(\mathrm{Fe}_{3-2}, \mathrm{Mn}_{0.8}\right) \mathrm{Si}_{2}(\mathrm{XRD})$ & 62.19 & 24.23 & 5.96 & 7.62 & - & - \\
\hline
\end{tabular}

Figure 6 shows the effect of the homogenization treatment on the volume fraction of the present phases. It is clear that homogenization at $390{ }^{\circ} \mathrm{C}$ leads to an increase in the volume fraction of particles by the formation of $\mathrm{MgZn}_{2}(\eta)$ and $\mathrm{Mg}_{2} \mathrm{Si}(\beta)$ precipitates. ${ }^{[33,34]}$ At $470{ }^{\circ} \mathrm{C}$, the volume fraction remains unchanged, while at $510{ }^{\circ} \mathrm{C}$ and $550{ }^{\circ} \mathrm{C}$, it decreases by the dissolution of $\mathrm{Al}_{17}\left(\mathrm{Fe}_{3.2} \mathrm{Mn}_{0.8}\right) \mathrm{Si}_{2}$ particles.

Figure 7 shows the typical results of the EPMA measurements of the Mn concentration from a line scan across a grain in a sample homogenized at $550{ }^{\circ} \mathrm{C}$ for 8 hours. It is clear that the $\mathrm{Mn}$ concentration in the regions close to the $\mathrm{Al}_{17}\left(\mathrm{Fe}_{3.2}, \mathrm{Mn}_{0.8}\right) \mathrm{Si}_{2}$ particles increases, which is attributed to the dissolution of $\mathrm{Al}_{17}\left(\mathrm{Fe}_{3.2}, \mathrm{Mn}_{0.8}\right) \mathrm{Si}_{2}$ particles during homogenization under this condition. This results in the formation of Mn-containing dispersoids close to the grain boundary. However, the $\mathrm{Mn}$ concentration in the grain interior changes slightly, as confirmed by the present EPMA analysis (Figure 7), mainly because of the low diffusion rate of $\mathrm{Mn}$ in the aluminum matrix. As a result, the $\mathrm{Mn}$ concentration is too small in the grain interior to form the Mn-containing dispersoids.

\section{Effect of Homogenization Treatment on Recrystallization Resistance}

Figure 8(a) shows the microstructure in the initial as-cast condition, which contains equiaxed grains with an average size of $200 \pm 10 \mu \mathrm{m}$. As shown in Figure 8(b), 


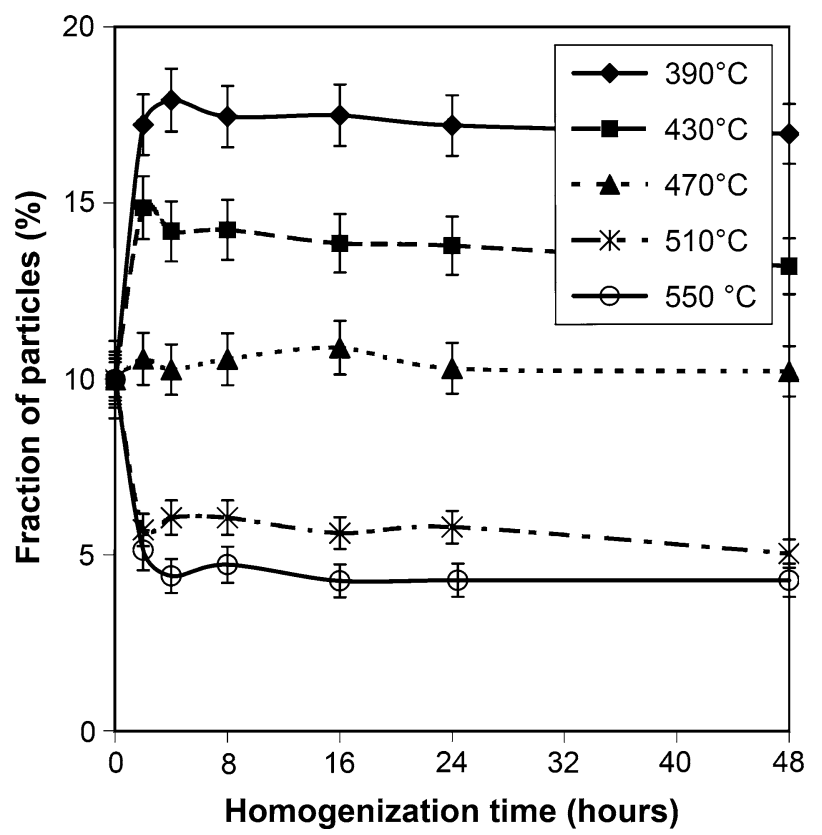

Fig. 6-Effect of homogenization time on the volume fraction of constitutive particles in sample N1 (optical microscopy).

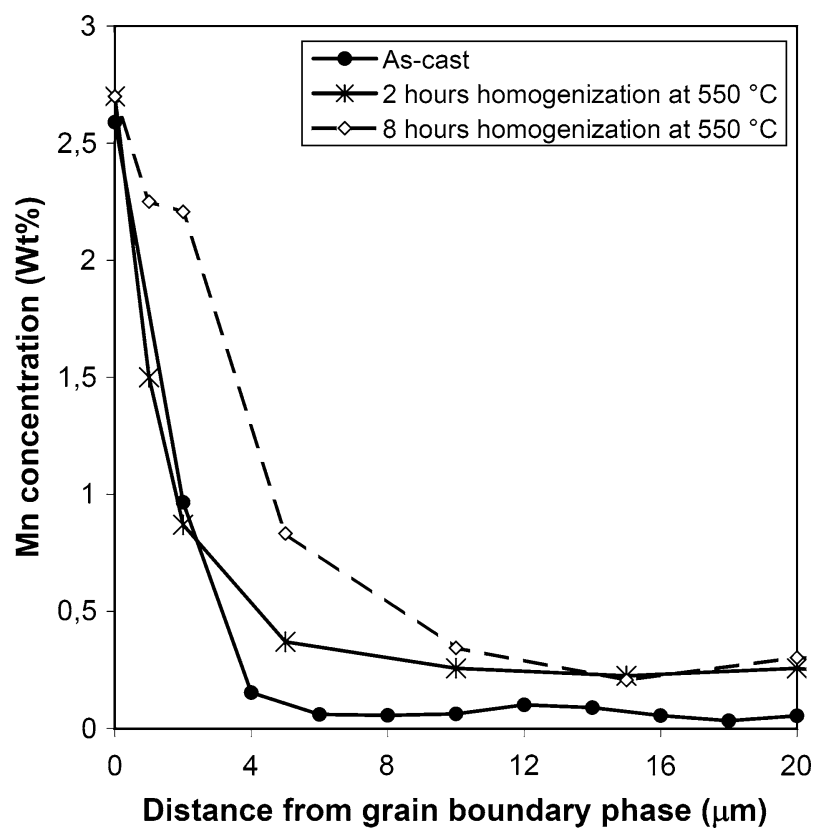

Fig. 7-Variation in the concentrations of $\mathrm{Mn}$ with the distance from the grain boundary to the grain interior, before and after homogenization at $550{ }^{\circ} \mathrm{C}$

after hot compression testing, the grains have been deformed.

Figure 9 shows the optical microstructure of the samples after hot compression until a strain of 0.6 and static annealing at $575^{\circ} \mathrm{C}$ for 10 minutes. It is clear that all of the specimens are recrystallized. The average grain size of the specimens is given in the figures. It can be seen that the specimen homogenized at $550{ }^{\circ} \mathrm{C}$ has the smallest grain size. In addition, the grain size of the

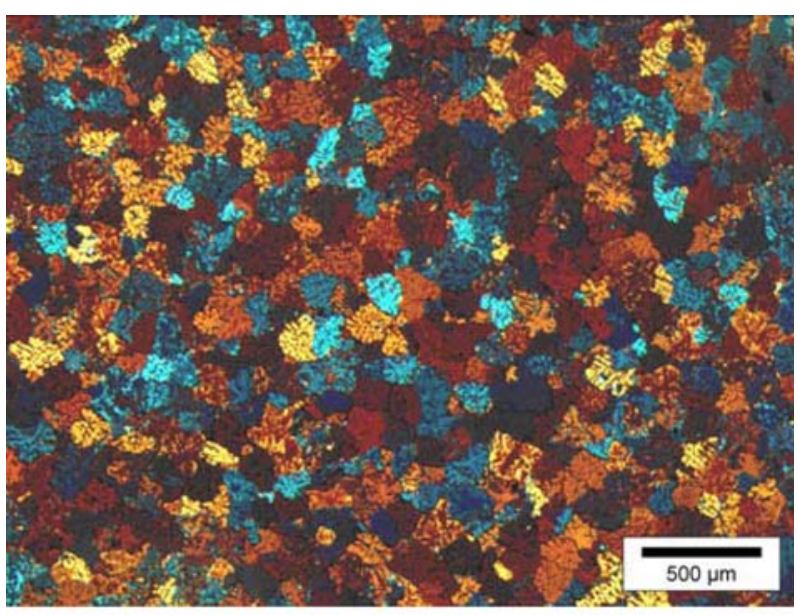

(a)

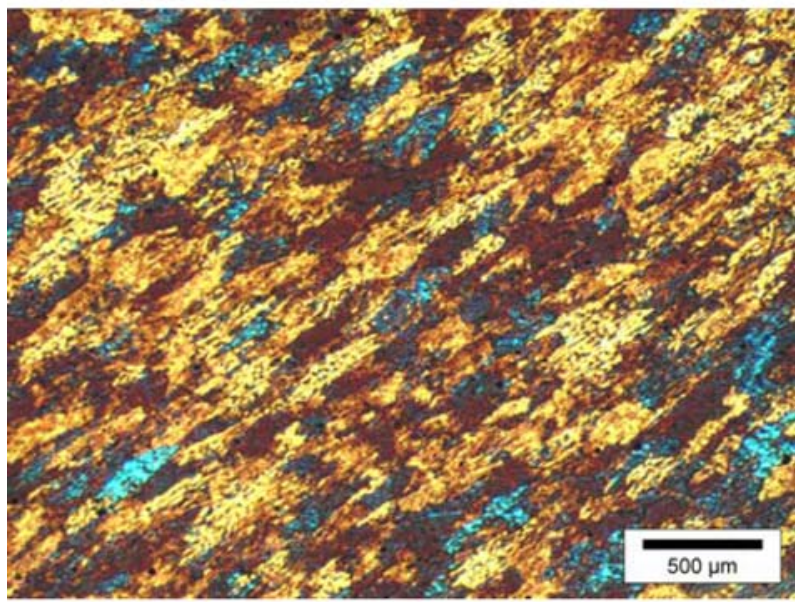

(b)

Fig. 8- Optical micrographs of sample N3 in the initial (a) as-cast and $(b)$ as-deformed states.

sample homogenized at $390{ }^{\circ} \mathrm{C}$ is smaller than that of the specimen homogenized at $470{ }^{\circ} \mathrm{C}$ or $510{ }^{\circ} \mathrm{C}$.

\section{DISCUSSION}

A. Correlation between Electrical Resistivity and Microstructure Evolution during Homogenization

1. Effect of chemical composition on electrical resistivity

The chemical compositions of the specimens vary in $\mathrm{Zr}$ and $\mathrm{Cr}$ content, as shown in Table I. According to Matthiessen's law (Eq. [1]), the electrical resistivity of an alloy is a function of the temperature-dependent electrical resistivity of the pure base metal $\left(\rho_{\text {pure }}(T)\right)$, the specific electrical resistivity of the elements in solid solution $\left(\rho_{i}\right)$, and their relative concentrations $\left(C_{i}\right):^{[18,35]}$

$$
\rho=\rho_{\text {pure }}(T)+\sum_{i} \rho_{i} C_{i}
$$

In Eq. [1], the second term represents the summation of the electrical resistivity contributions from the various 


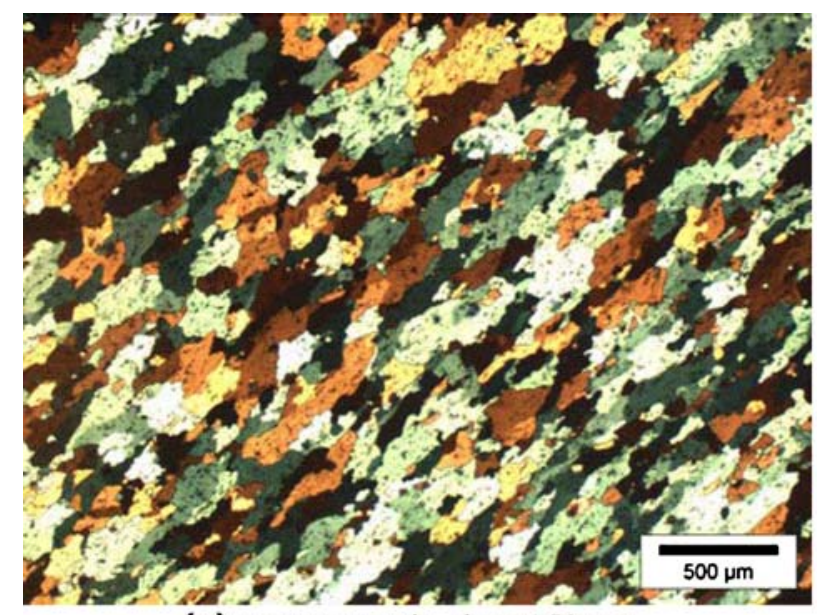

(a) average grain size $=153 \mu \mathrm{m}$

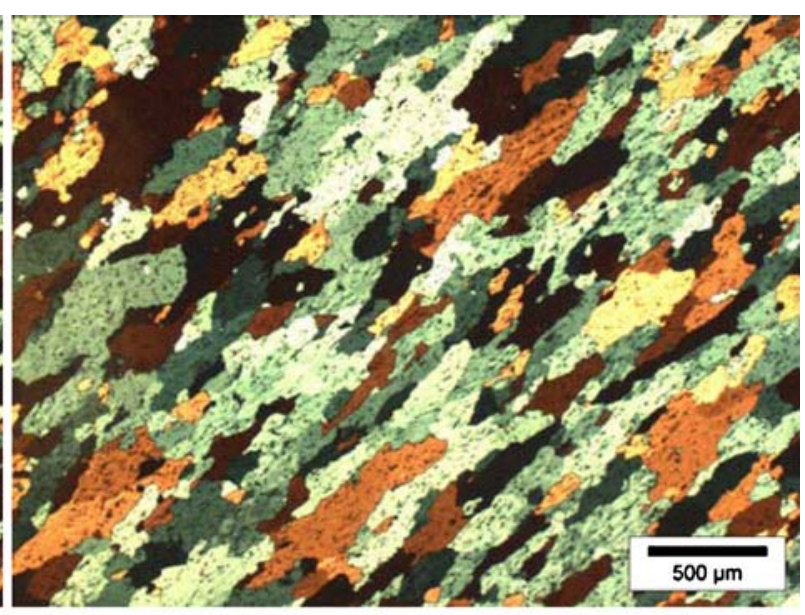

(b) average grain size $=310 \mu \mathrm{m}$

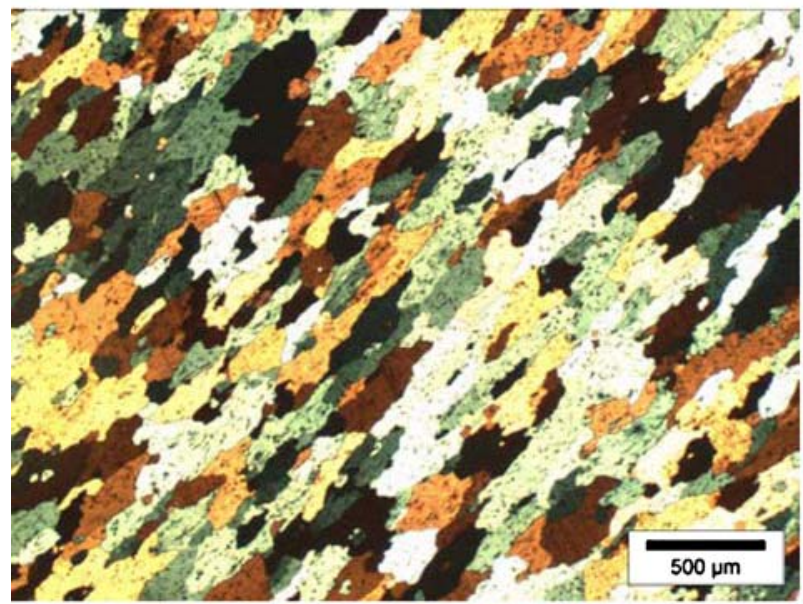

(c) average grain size $=225 \mu \mathrm{m}$

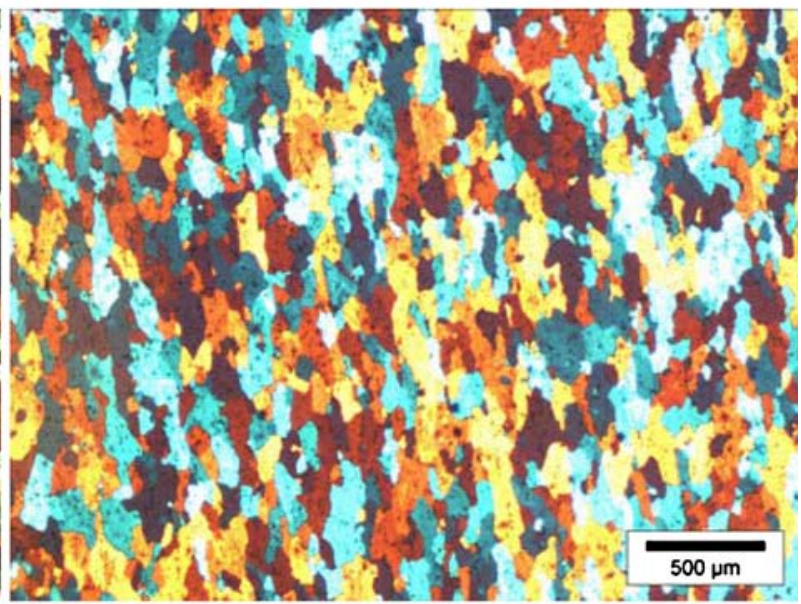

(d) average grain size $=127 \mu \mathrm{m}$

Fig. 9-Effect of static annealing at $575^{\circ} \mathrm{C}$ for $10 \mathrm{~min}$, after hot compression tests, on the specimens homogenized for $24 \mathrm{~h}$ at $(a) 390{ }^{\circ} \mathrm{C}$, (b) $470{ }^{\circ} \mathrm{C}$, (c) $510{ }^{\circ} \mathrm{C}$, and (d) $550{ }^{\circ} \mathrm{C}$.

Table IV. Electrical Resistivity of Pure Alloying Elements Present in Material ${ }^{[36]}$

\begin{tabular}{lcccccccc}
\hline Solute & $\mathrm{Mg}$ & $\mathrm{Si}$ & $\mathrm{Cu}$ & $\mathrm{Zn}$ & $\mathrm{Fe}$ & $\mathrm{Mn}$ & $\mathrm{Zr}$ & $\mathrm{Ti}$ \\
\hline$\Delta \rho(\mathrm{n} \Omega \cdot \mathrm{m} / \mathrm{wt} \mathrm{pct})$ & 6.11 & 6.68 & 3.32 & 1.01 & 38.00 & 31.43 & 18.48 & 31.92 \\
\hline
\end{tabular}

solid solution elements; $\rho_{i}$ is the specific electrical resistivity of the $i$ th solute and $C_{i}$ is the concentration of this solute.

Table IV shows the contribution of solutes in the electrical resistivity of the aluminum alloys. ${ }^{[36]}$ It can be seen that $\mathrm{Fe}$ and $\mathrm{Mn}$ have relatively greater contributions to increasing the electrical resistivity as compared to the other elements. This indicates that Fe and $\mathrm{Mn}$ are the primary controlling elements of the measured electrical resistivity among all the elements present in the alloy. The third effective element relative to the electrical resistivity is $\mathrm{Zr}$. The increase in electrical resistivity from N1 to $\mathrm{N} 3$ (Figure 1) is related to the increase in the amount of $\mathrm{Zr}$. By an increase in $\mathrm{Zr}$ content from $\mathrm{N} 1$ ( $0.08 \mathrm{wt}$ pct) to $\mathrm{N} 2(0.13 \mathrm{wt} \mathrm{pct})$ or from $\mathrm{N} 2(0.13 \mathrm{wt}$ pct) to $\mathrm{N} 3(0.2 \mathrm{wt} \mathrm{pct})$, the electrical resistivity of the alloy increases by 2 to 3 pct. In addition, N4, with a higher $\mathrm{Cr}$ content (0.4 pct) than the other samples, exhibits the highest electrical resistivity. The large effect of $\mathrm{Cr}$ on the electrical resistivity is also due to the large electrical resistivity of pure $\mathrm{Cr}$ compared to other elements, ${ }^{[18,35]}$ as shown in Table IV.

\section{Effect of homogenization heat treatment} on electrical resistivity

In the presence of secondary particles, the primary effective parameters on the electrical resistivity are as follows: ${ }^{[35]}$ (1) the volume fraction of fine and coherent particles in the structure, (2) the particle interspacing, and (3) the concentration of elements in solid solution.

The formation of dispersoids leads to a decrease in the concentration of the corresponding elements in the matrix. If the elements precipitate out during a thermal process such as homogenization or precipitation 
hardening, the change in the electrical resistivity of the material depends on the size and the interface of the newly formed particles. ${ }^{[17-21]}$ If the new particles are small and coherent, the electrical resistivity of the material increases and vice versa. ${ }^{[35]}$ During homogenization of the as-cast 7XXX-series aluminum alloys, the following two major changes in the structure are expected: $:^{[1,10-12,37]}$ (1) the formation of small particles or dispersoids largely from $\mathrm{Zr}, \mathrm{Cr}, \mathrm{Fe}$, and $\mathrm{Mn}$ and (2) the dissolution of constitutive particles and the formation of new ones, depending on the homogenization temperature and holding time.

Regardless of the interface of the dispersoids formed, it is expected that, if the particle interspacing is greater than the required free-passing distance of the electrons (i.e., for precipitate interspacing of $100 \mathrm{~nm}$ and larger in aluminum alloys), the effect of particles is negligible. ${ }^{[18,35]}$ Previous investigations show that the distances between the dispersoids vary depending on the homogenization treatment conditions. ${ }^{10-12]}$ However, in the present investigation, as shown in Figure 4, the dispersoid interspacing is larger than $150 \mathrm{~nm}$, regardless of the homogenization treatment employed. Thus, there is no increase in the electrical resistivity expected due to the formation of dispersoids. The formation of dispersoids is consistent with the depletion of the corresponding alloying elements from the structure, which may result in a decrease in the electrical resistivity as discussed later.

From Table II, it is clear that the compositions of the small dispersoids formed during homogenization are primarily enriched with $\mathrm{Zr}, \mathrm{Cr}, \mathrm{Mn}, \mathrm{Fe}$, and some other elements. The fourth type of dispersoid is composed of other elements such as $\mathrm{Zn}$ and $\mathrm{Mg}$ that affect the electrical resistivity insignificantly. Previous investigations showed that this type of dispersoid is very rarely found in the homogenized structure of AA7020 alloy. ${ }^{[32]}$ Because the elements constituting the fourth type of dispersoid are less effective on the electrical resistivity compared to $\mathrm{Zr}, \mathrm{Cr}, \mathrm{Mn}$, and $\mathrm{Fe}$, and also due to the negligible number density of these dispersoids, the following discussion will be focused on the first three types of dispersoids. As discussed earlier, $\mathrm{Zr}, \mathrm{Cr}, \mathrm{Mn}$, and $\mathrm{Fe}$ can affect the electrical resistivity of the alloy significantly. It should be noted that the Mn-containing dispersoids are only formed during homogenization at temperatures higher than $510^{\circ} \mathrm{C}$ and holding times larger than 4 hours. The formation of these small particles leads to the depletion of these elements in the matrix, which results in a continuous decrease in the electrical resistivity of the samples, in agreement with Reference 5.

According to Mattiessen's law, another effective factor on the electrical resistivity is the concentration of elements present in the structure. It is clear in Table I that the concentrations of $\mathrm{Si}, \mathrm{Cu}, \mathrm{Mg}$, and $\mathrm{Zn}$, which are likely to dissolve in the aluminum solid solution, are relatively higher than those of $\mathrm{Zr}, \mathrm{Mn}, \mathrm{Cr}$, and $\mathrm{Fe}$, which are depleted out of the structure. This may indicate that the effect of smaller concentrations of $\mathrm{Zr}$, $\mathrm{Mn}, \mathrm{Cr}$, and $\mathrm{Fe}$ on the increase in electrical resistivity is larger than the effect of larger amounts of $\mathrm{Si}, \mathrm{Cu}, \mathrm{Mg}$, and $\mathrm{Zn}$. This is consistent with the data presented in Table IV illustrating the electrical resistivity of the pure elements.

It is clear in Figure 6 that homogenization at $390{ }^{\circ} \mathrm{C}$ leads to an increase in the volume fraction of large particles. At $470{ }^{\circ} \mathrm{C}$, the volume fraction remains unchanged, while at $510{ }^{\circ} \mathrm{C}$ and $550{ }^{\circ} \mathrm{C}$, it decreases. At a low-temperature homogenization $\left(390{ }^{\circ} \mathrm{C}\right)$, the dissolution of the large particles does not occur and large $\eta$ and $\beta$ precipitates form. ${ }^{[33]}$ Therefore, the electrical resistivity curve in Figure 2 shows a continuous decrease up to 48 hours of homogenization, ${ }^{[21,35]}$ due to the depletion of $\mathrm{Zr}$ and $\mathrm{Cr}$ in the matrix by forming dispersoids and the depletion of $\mathrm{Mg}, \mathrm{Si}$, and $\mathrm{Zn}$ by the forming of $\eta$ and $\beta$ precipitates.

During high-temperature homogenization, however, the dissolution of the large particles, including the $\mathrm{Al}_{17}\left(\mathrm{Fe}_{3.2} \mathrm{Mn}_{0.8}\right) \mathrm{Si}_{2}$ particles that account for a considerable percentage of $\mathrm{Fe}$ and $\mathrm{Mn}$, occurs. Therefore, the presence of $\mathrm{Mn}$-containing dispersoids after homogenization at $510{ }^{\circ} \mathrm{C}$ or $550{ }^{\circ} \mathrm{C}$ for more than 2 hours is consistent with the dissolution of the $\mathrm{Al}_{17}\left(\mathrm{Fe}_{3.2} \mathrm{Mn}_{0.8}\right) \mathrm{Si}_{2}$ particles. It can be concluded that, during homogenization at temperatures lower than $470{ }^{\circ} \mathrm{C}$, the $\mathrm{Al}_{17}\left(\mathrm{Fe}_{3.2} \mathrm{Mn}_{0.8}\right) \mathrm{Si}_{2}$ particles are not dissolved in the structure and the concentrations of $\mathrm{Fe}$ and $\mathrm{Mn}$ in the solid solution are not enough for the formation of Mn-containing dispersoids.

Among all the elements present in the AA7020 aluminum alloy, $\mathrm{Mn}$ is the only one that has a mutual effect. In other words, $\mathrm{Fe}$ and $\mathrm{Mn}$ are present in the $\mathrm{Al}_{17}\left(\mathrm{Fe}_{3.2} \mathrm{Mn}_{0.8}\right) \mathrm{Si}_{2}$ particles and become dissolved during homogenization at high temperatures, resulting in higher $\mathrm{Fe}$ and $\mathrm{Mn}$ concentrations in the solid solution. They are also present in the third type of dispersoid, which precipitates out during homogenization. As shown in Table IV, Fe and $\mathrm{Mn}$ are the most effective elements that can cause changes in the electrical resistivity. Because the electrical resistivity of the alloy decreases during homogenization at high temperatures, while the $\mathrm{Al}_{17}\left(\mathrm{Fe}_{3.2} \mathrm{Mn}_{0.8}\right) \mathrm{Si}_{2}$ particles are dissolving, it may be concluded that the percentages of $\mathrm{Fe}$ and $\mathrm{Mn}$ dissolving in the structure from the $\mathrm{Al}_{17}\left(\mathrm{Fe}_{3.2} \mathrm{Mn}_{0.8}\right) \mathrm{Si}_{2}$ particles are equal to or less than the percentages of these elements depleting out from the structure by the formation of the third type of dispersoid.

The formation of the plateau in the electrical resistivity curve (Figure 2) may be due to the balance of the increase in the concentrations of some elements, namely, $\mathrm{Si}, \mathrm{Mg}$, and $\mathrm{Zn}$ in the matrix, and the depletion of other elements such as $\mathrm{Zr}$ and $\mathrm{Cr}$ out of the matrix. When the rate of the increase in the electrical resistivity due to the dissolution of constitutive particles and, therefore, the enrichment of the structure becomes equal to the rate of the decrease in the electrical resistivity due to the formation of $\mathrm{Zr}$ - and $\mathrm{Cr}$-containing dispersoids, a peak or plateau is observed in the electrical resistivity curve.

\section{B. Optimum Homogenization Treatment}

Figures 2(c) and (d) show that, during homogenization at $510{ }^{\circ} \mathrm{C}$ and $550{ }^{\circ} \mathrm{C}$, the decrease in the electrical 
resistivity values stops after 16 to 24 hours of homogenization, while during homogenization at low temperatures $\left(390{ }^{\circ} \mathrm{C}\right)$, the reduction in the electrical resistivity continues until 48 hours. This indicates that, at high temperatures, the structure is depleted of $\mathrm{Mn}, \mathrm{Cr}$, and $\mathrm{Zr}$ (in equilibrium with the phase diagrams) after 16 to 24 hours. Hence, it can be concluded that a homogenization treatment for more than 16 to 24 hours does not affect the formation of the dispersoids at high temperatures. This is in agreement with the findings from other investigations of the influence of homogenization treatment on the formation of dispersoids in the AA7475 aluminum alloy. ${ }^{[31]}$ At $390{ }^{\circ} \mathrm{C}$, even after 48 hours, there are still $\mathrm{Mn}, \mathrm{Zr}$, and $\mathrm{Cr}$, which tend to precipitate out, resulting in a decrease in the electrical resistivity curve.

The dispersoid interspacing decreases up to 16 to 24 hours of the homogenization treatment at high temperatures, which indicates that the number density of dispersoids keeps increasing. This increase in the number density continues up to 48 hours at $390{ }^{\circ} \mathrm{C}$. The increase in the dispersoid interspacing at $550{ }^{\circ} \mathrm{C}$ after 48 hours indicates that coarsening takes place, which results in a decrease in the number density of dispersoids, at a constant volume fraction. These results are consistent with the observations from the electrical resistivity (Figure 2), namely that the decrease in the electrical resistivity stops after approximately 16 to 24 hours of homogenization at temperatures higher than $470{ }^{\circ} \mathrm{C}$.

One of the primary objectives of homogenization is to form small Mn-, Zr-, and Cr-containing dispersoids. ${ }^{[1]}$ The lowest electrical resistivity of the sample homogenized at $550{ }^{\circ} \mathrm{C}$ for 24 hours is consistent with the formation of a large volume fraction of dispersoids, leading to the depletion of solutes in the matrix. Therefore, based on the findings of this investigation, the homogenization treatment at $550{ }^{\circ} \mathrm{C}$ has resulted in the largest volume fraction of dispersoids, with a noticeably higher number density. Therefore, this temperature is considered as an optimum one for the homogenization of this alloy.

An increase in the holding time, especially at high temperatures, which results in the coarsening of the dispersoids, ${ }^{[1]}$ is not desirable. Therefore, it is not recommended that the homogenization treatment be carried out under conditions in which the electrical resistivity curve remains unchanged. This indicates that, when high homogenization temperatures $\left(510{ }^{\circ} \mathrm{C}\right.$ and $550{ }^{\circ} \mathrm{C}$ ) are used, the homogenization treatment should proceed up to 16 to 24 hours only. However, at $390{ }^{\circ} \mathrm{C}$, treatments up to 48 hours are still viable. The viability of the proposed optimum homogenization treatment is evidenced by the microstructural evolution after hot compression, as will be discussed later.

\section{Effect of Homogenization Heat Treatment on Recrystallization Response of Alloy}

In a recrystallized sample, such as those found in this study and presented in Figure 9, grain growth occurs to decrease the energy level of the material by combining small grains and, therefore, decreasing the surface boundaries. Growth is only halted when the migrating recrystallization front encounters sufficient dispersoids to be pinned as a result of the Zener drag effect. ${ }^{[38-40]}$ Assuming a random spatial correlation between the boundaries and the dispersoids, the Zener drag resulting from coherent particles ${ }^{[38]}$ is given by

$$
P_{\mathrm{Z}}=\frac{3 \gamma V_{f}}{r}
$$

where $V_{f}$ is the local volume fraction of the dispersoids, $r$ the particle radius, and $\gamma$ the energy of the boundary that the dispersoids are pinning. It can be seen from this relationship that the Zener drag due to the dispersoids is maximized by maximizing the volume fraction $\left(V_{f}\right)$ and minimizing the particle size. At a critical value of the $V_{f} / r$ ratio, the Zener drag will become sufficiently large to overcome the driving force for boundary migration that hinders recrystallization. Therefore, the smallest grain size of the samples homogenized at $550{ }^{\circ} \mathrm{C}$ for 24 hours $(127 \pm 15 \mu \mathrm{m})$ is due to the strongest recrystallization inhibition as a result of the presence of the dispersoids. This is in contradiction to the current understanding, which shows that a homogenization treatment at a low temperature results in a stronger recrystallization inhibition. ${ }^{[10-16]}$ This may be because the Mn-containing dispersoids, which can play a significant role in retarding recrystallization, form during homogenization at high temperatures, namely, above $510{ }^{\circ} \mathrm{C}$. The formation of Mn-containing dispersoids is dependent on the dissolution of the $\mathrm{Al}_{17}\left(\mathrm{Fe}_{3.2} \mathrm{Mn}_{0.8}\right) \mathrm{Si}_{2}$ particles. Therefore, the higher recrystallization resistance of the sample homogenized at $550{ }^{\circ} \mathrm{C}$ is related to the larger volume fraction of dispersoids, because these samples contain the Mn-containing dispersoids together with the other types. The lowest electrical resistivity of the samples homogenized at $550{ }^{\circ} \mathrm{C}$ is a proof of the largest volume fraction of dispersoids. This, together with the smallest dispersoid interspacing for samples homogenized at $550{ }^{\circ} \mathrm{C}$, provides the highest Zener drag pressure for these samples.

The dispersoid-free zones in the interdendritic regions close to the original grain boundaries play a critical role in the occurrence of recrystallization. The grain boundaries are populated by large $\mathrm{Al}_{17}\left(\mathrm{Fe}_{3.2} \mathrm{Mn}_{0.8}\right) \mathrm{Si}_{2}$ particles formed during solidification. These particles are large enough to stimulate the nucleation of recrystallized grains during solution treatment. ${ }^{[38,40]}$ According to Robson, ${ }^{[10,12]}$ there are few $\mathrm{Zr}$-containing dispersoids present in the adjacent material close to the grain boundaries. This, together with nuclei stimulation on the large $\mathrm{Al}_{17}\left(\mathrm{Fe}_{3.2} \mathrm{Mn}_{0.8}\right) \mathrm{Si}_{2}$ particles, results in a growth possibility for new grains from the deformation zones surrounding the particles and into the surrounding matrix. The lower number density of dispersoids at the grain-boundary regions is due to the solidification segregation that results in lower concentrations of pretectic elements such as $\mathrm{Zr} .^{[10]}$ One of the possible ways proposed by Robson ${ }^{[12]}$ to avoid the condition of making islands with a small number of $\mathrm{Zr}$-containing dispersoids at the grain-boundary regions was the addition of Sc. He modeled and concluded that an 
addition of scandium could eliminate the dispersoid-free zones observed in scandium-free 7050, greatly increasing recrystallization resistance.

The formation of Mn-containing dispersoids is dependent on the dissolution of the $\mathrm{Al}_{17}\left(\mathrm{Fe}_{3.2} \mathrm{Mn}_{0.8}\right) \mathrm{Si}_{2}$ particles. Because the $\mathrm{Al}_{17}\left(\mathrm{Fe}_{3.2} \mathrm{Mn}_{0.8}\right) \mathrm{Si}_{2}$ particles are likely to be dissolved during homogenization, ${ }^{[34]}$ the concentrations of the elements that constitute the $\mathrm{Al}_{17}\left(\mathrm{Fe}_{3.2} \mathrm{Mn}_{0.8}\right) \mathrm{Si}_{2}$ particles increase in the regions close to the $\mathrm{Al}_{17}\left(\mathrm{Fe}_{3.2} \mathrm{Mn}_{0.8}\right) \mathrm{Si}_{2}$ particles due to the dissolution and remain unchanged far from that, as shown in Figure 7. These local increases in the concentrations due to the dissolution of the $\mathrm{Al}_{17}\left(\mathrm{Fe}_{3.2} \mathrm{Mn}_{0.8}\right) \mathrm{Si}_{2}$ particles have been reported. ${ }^{[34]}$ During homogenization, an increase in the concentration of $\mathrm{Mn}$ results in a larger number density of dispersoids at the grainboundary regions, which inherently contain a small number of Zr-containing dispersoids. ${ }^{[10-12]}$ Therefore, stronger recrystallization inhibition occurs to the samples homogenized at $550{ }^{\circ} \mathrm{C}$.

Among the other samples examined after hot compression and subsequent annealing (those homogenized at $390{ }^{\circ} \mathrm{C}$ and $470{ }^{\circ} \mathrm{C}$ for 24 hours), the one homogenized at $390{ }^{\circ} \mathrm{C}$ shows the smallest recrystallized grain size $(153 \pm 20 \mu \mathrm{m})$. In the samples homogenized at $390{ }^{\circ} \mathrm{C}$ and $470{ }^{\circ} \mathrm{C}$, the formation of the Mn-containing dispersoids is not expected. Therefore, the volume fraction of dispersoids is originally smaller because one type of dispersoid is missing, namely, the Mn-containing one. Regarding the other types of dispersoids, i.e., the $\mathrm{Cr}$ - and $\mathrm{Zr}$-containing ones, because their formation is a nucleation and growth process, at lower homogenization temperatures, e.g., $390{ }^{\circ} \mathrm{C}$, the number density of dispersoids increases significantly compared to $470{ }^{\circ} \mathrm{C}$. In addition, a smaller particle size is obtained. This results in a larger Zener drag pressure $\left(P_{\mathrm{Z}}\right)$ and, consequently, the samples homogenized at $390{ }^{\circ} \mathrm{C}$ show a good recrystallization resistance.

\section{CONCLUSIONS}

The effect of the variations in $\mathrm{Zr}$ and $\mathrm{Cr}$ contents in the chemical composition of the AA7020 aluminum alloy on the electrical resistivity and its evolution during homogenization was investigated. The correlation between the electrical resistivity, dispersoid formation, and particle dissolution during the homogenization of AA7020 with different $\mathrm{Zr}$ and $\mathrm{Cr}$ contents was established. An optimum treatment with regard to the recrystallized grain size was proposed and its viability on recrystallization inhibition was assessed through hot compression tests and static annealing. Based on the results of this investigation, the following conclusions were drawn.

1. The electrical resistivity of the alloy decreased as the homogenization time increased, which is due to the depletion of $\mathrm{Zr}$ and $\mathrm{Cr}$ in the structure the formation of small $\mathrm{Zr}$ - and $\mathrm{Cr}$-containing dispersoids at low temperatures, i.e., lower than $510{ }^{\circ} \mathrm{C}$, and together with Mn-containing dispersoids at higher temperatures. The presence of a peak or plateau, indicating no change in the electrical resistivity curve, which occurs between 2 and 8 hours of homogenization at high temperatures, i.e., $510{ }^{\circ} \mathrm{C}$ and $550{ }^{\circ} \mathrm{C}$, may be attributed to the dissolution of constitutive particles into the structure.

2. An optimum homogenization treatment has been proposed based on the observation of the smallest electrical resistivity that is consistent with the largest volume fraction of dispersoids. This observation is related to the dissolution of $\mathrm{Fe}$ - and $\mathrm{Mn}$-rich $\mathrm{Al}_{17}\left(\mathrm{Fe}_{3.2} \mathrm{Mn}_{0.8}\right) \mathrm{Si}_{2}$ particles during homogenization at high temperatures and, consequently, the possibility of the formation of Mn-containing dispersoids at the grain-boundary regions in the vicinity of $\mathrm{Al}_{17}\left(\mathrm{Fe}_{3.2} \mathrm{Mn}_{0.8}\right) \mathrm{Si}_{2}$ particles. Thus, homogenization at a higher temperature; i.e., $550{ }^{\circ} \mathrm{C}$, a holding time more than 24 hours is not necessary, while at lower temperatures (e.g., $390{ }^{\circ} \mathrm{C}$ ), holding up to 48 hours is advantageous. Therefore, an optimum homogenization treatment at $550{ }^{\circ} \mathrm{C}$ for 24 hours is proposed for the AA7020 aluminum alloy.

3. The microstructure of the alloy after hot compression tests and annealing confirmed that the optimum homogenization treatment corresponds to a smaller recrystallized grain size, which is likely due to a stronger recrystallization inhibition effect as a result of a larger volume fraction and number density of grain-boundary-pinning dispersoids.

\section{ACKNOWLEDGMENTS}

This research was carried out under Project No. MC 4.04203 in the framework of the Research Program of the Materials Innovation Institute, M2i (Delft, The Netherlands) (www.m2i.nl), the former Netherlands Institute for Metals Research. The authors acknowledge Messrs. K. Kwakernaak and E.R. Peekstok for assistance in microstructural examinations.

\section{OPEN ACCESS}

This article is distributed under the terms of the Creative Commons Attribution Noncommercial License which permits any noncommercial use, distribution, and reproduction in any medium, provided the original author(s) and source are credited.

\section{REFERENCES}

1. T. Sheppard: Extrusion of Aluminum Alloys, Kluwer Academic Publishers, Dordrecht, The Netherlands, 1999, pp. 227-52.

2. M. Peters, J. Eschweiler, and K. Welpmann: Scripta Metall., 1986, vol. 20 (2), pp. 259-64.

3. O. Daaland and E. Nes: Acta Mater., 1996, vol. 44, pp. 1389-1411.

4. Y.J. Li and L. Arnberg: Acta Mater., 2003, vol. 51 (12), pp. 341528.

5. L. Lodgaard and N. Ryum: Mater. Sci. Eng., A, 2000, vol. 283, pp. $144-52$. 
6. M. Cabibbo, E. Evangelista, C. Scalabroni, and E. Bonetti: Mater. Sci. Forum, 2006, vols. 503-504, pp. 841-46.

7. L. Lodgaard and N. Ryum: Mater. Sci. Technol., 2000, vol. 16 (6), pp. 599-604.

8. D.H. Lee, J.H. Park, and S.W. Nam: Mater. Sci. Technol., 1999, vol. 15 (4), pp. $450-55$.

9. R.A. Jeniski, B. Thanaboonsombut, and T.H. Sanders: Metall. Mater. Trans. A, 1996, vol. 27A, pp. 19-27.

10. J.D. Robson and P.B. Prangnell: Acta Mater., 2001, vol. 49, pp. 599-613.

11. J.D. Robson: Mater. Sci. Eng., A, 2002, vol. 338, pp. 219-29.

12. J.D. Robson: Acta Mater., 2004, vol. 52, pp. 1409-21.

13. S.V. Senkova, O.N. Senkov, and D.B. Miracle: Metall. Mater. Trans. A, 2006, vol. 37A, pp. 3569-75.

14. O.N. Senkov, R.B. Bhat, S.V. Senkova, and J.D. Schloz: Metall. Mater. Trans. A, 2005, vol. 36A, pp. 2115-26.

15. B. Morere, R. Shahani, C. Maurice, and J. Driver: Metall. Mater. Trans. A, 2001, vol. 32A, pp. 625-32.

16. A. Deschamps and Y. Bréchet: Mater. Sci. Eng., A, 1998, vol. 251 (1-2), pp. 200-07.

17. C. Panseri and T. Federighi: J. Inst. Met., 1966, vol. 94, pp. 99107.

18. P.L. Rossiter: The Electrical Resistivity of Metals and Alloys, Cambridge University Press, Cambridge, United Kingdom, 1987, pp. 1-73.

19. J.T. Edwards and A.J. Hillel: Philos. Mag., 1977, vol. 35 (5), pp. 1221-29.

20. A. Thakur, R. Raman, and S.N. Malhorta: J. Mater. Process. Technol., 2007, vol. 194, pp. 184-86.

21. S. Esmaeili, D.J. Lloyd, and W.J. Poole: Mater. Lett., 2005, vol. 59 (5), pp. 575-77.

22. R. Ferragut, A. Somoza, and I. Torriani: Mater. Sci. Eng., A, 2002, vol. 334 (1-2), pp. 1-5.

23. K. Asano, M. Abe, and A. Fujiwara: Mater. Sci. Eng., 1976, vol. 22 (1), pp. 61-70.

24. I. Kovács, J. Lendvai, and T. Ungár: Mater. Sci. Eng., A, 1975, vol. 21, pp. 169-75.
25. E. Cerri and P. Leo: Mater. Sci. Eng., A, 2005, vols. 410-411, pp. 226-29.

26. M.A. Gaffar, A. Gaber, M.S. Mostafa, and E.F. Abo Zeid: Mater. Sci. Eng., A, 2007, vol. 465 (1-2), pp. 274-82.

27. Y. Li and L. Arnberg: TMS Light Metals, TMS, Warrendale, PA, 2003, pp. 991-97.

28. S.I. Vooijs, S.B. Davenport, I. Todd, and S. Van Der Zwaag: Philos. Mag., 2001, vol. 8 (8), pp. 2059-72.

29. F.A. Sloof, J. Zhou, and J. Duszczyk: 7th Int. Conf. Magnesium Alloys and Their Applications, Wiley-VCH, Weinheim, Germany, 2006, pp. 324-29.

30. "ASTM E 112-96 Standard Test Methods for Determining Average Grain Size," Annual Book of ASTM Standards, ASTM International, West Conshohocken, PA, 2004, vol. 03.01, pp. 1-26.

31. H. Ahmed, A.R. Eivani, J. Zhou, and J. Duszczyk: Proc. 11th Int. Conf. on Aluminum Alloys, Wiley-VCH Verlag $\mathrm{GmbH} \&$ Co. KGaA, Aachen, Germany, 2008, vol. 1, pp. 621-28.

32. A.R. Eivani, H. Ahmed, J. Zhou, and J. Duszczyk: unpublished research, 2009.

33. A.R. Eivani, H. Ahmed, J. Zhou, and J. Duszczyk: Metall. Mater. Trans. A, 2009, vol. 40A, pp. 717-28.

34. A.R. Eivani, H. Ahmed, J. Zhou, and J. Duszczyk: Proc. 11th Int. Conf. on Aluminum Alloys (ICAA 11), Wiley-VCH Verlag GmbH \& Co. KGaA, Aachen, Germany, 2008, pp. 993-99.

35. B. Raeisinia, W.J. Poole, and D.J. Lloyd: Mater. Sci. Eng., A, 2006, vol. 420, pp. 245-49.

36. K. Matsumoto, S. Komatsu, M. Ikeda, B. Verlinden, and P. Ratchev: Mater. Trans. JIM, 2000, vol. 41, pp. 1275-81.

37. A. Jackson and T. Sheppard: Proc. 6th Int. Aluminum Extrusion Technol. Conf., Aluminum Association, Washington, DC, 1996, vol. 1, pp. 541-50.

38. F.J. Humphreys and M. Hatherly: Recrystallization and Related Annealing Phenomena, Elsevier Science, Inc., Oxford, United Kingdom, 1995, pp. 109-14.

39. C.S. Smith: Trans. TMS-AIME, 1948, vol. 175, pp. 15-51.

40. M.F. Ashby, J. Harper, and J. Lewis: Trans. TMS-AIME, 1969, vol. 245 , pp. 413-20. 